\title{
Meropenem-induced pancytopenia in a preterm neonate: a case report
}

\author{
Kashif Hussain ${ }^{1}$, Muhammad Sohail Salat ${ }^{2}$, Naureen Mohammad ${ }^{1}$, Ambreen Mughal $^{1}$, Sidra Idrees ${ }^{2}$, \\ Javaid lqbal ${ }^{2}$ and Gul Ambreen ${ }^{1 *}$ (1)
}

\begin{abstract}
Background: A post-marketing surveillance study has reported an association between meropenem use and the incidence of hematologic abnormalities, including leukopenia, thrombocytopenia, hemolysis, and neutropenia, but the precise incidence in neonates is unknown. Here, we report meropenem-induced pancytopenia in a preterm neonate.
\end{abstract}

Case presentation: A preterm newborn Pakistani received intravenous meropenem $40 \mathrm{mg} / \mathrm{kg}$ every 8 hours to treat Klebsiella pneumoniae in blood cultures and suspected meningitis. The baby developed severe thrombocytopenia, with a platelet count of $22 \times 10^{3} \mathrm{cell} / \mathrm{s} / \mathrm{mm}^{3}$, low hemoglobin level of $9.7 \mathrm{~g} / \mathrm{dl}$, and low absolute neutrophil count (ANC) of 816 cells $/ \mathrm{mm}^{3}$ on days 3, 14, and 17 of meropenem therapy, respectively. Based on the blood culture and institutional guidelines, meropenem treatment was continued with monitoring and supportive care for a total of 19 days. After discontinuation of meropenem, the baby was monitored continuously for hematological changes, and low counts persisted for 3 days. ANC improved to $>1500 \mathrm{cell} / \mathrm{s} / \mathrm{mm}^{3}$ on the fourth day, and the platelet count reached $>150 \times 10^{3}$ cells $/ \mathrm{mm}^{3}$ for the first time on the seventh day of meropenem discontinuation. All subsequent complete blood count $(\mathrm{CBC})$ reports showed improving trends. The baby was discharged on the 48th day of life (DOL), with follow-up monitoring of CBC. The baby was kept on iron supplements, and hemoglobin level of $11.2 \mathrm{~g} / \mathrm{dl}$ was observed on the 59th DOL.

Conclusion: Neonatal pancytopenia may lead to serious health complications; therefore, clinicians and pharmacists need to vigilantly monitor CBC in this vulnerable population, even when administering meropenem in septic doses for the recommended duration.

Keywords: Meropenem, Preterm neonate, Pancytopenia, Absolute neutrophil count, Hematological problems

\section{Background}

Pancytopenia is defined as reduced white blood cell (WBC) count, hemoglobin, and platelet count. Pancytopenia occurs when hemoglobin is $<13 \mathrm{~g} / \mathrm{dl}$ in males and $<12 \mathrm{~g} / \mathrm{dl}$ in females, absolute neutrophil count (ANC) is $<1500$ cells $/ \mathrm{mm}^{3}$, and platelet count is $<150 \times 10^{3}$ cells $/ \mathrm{mm}^{3}$ [1]. Pancytopenia is considered

*Correspondence: gul.ambreen@aku.edu

${ }^{1}$ Department of Pharmacy, Main Pharmacy Aga Khan University Hospital, Stadium Road, P.O Box 3500, Karachi 74800, Pakistan

Full list of author information is available at the end of the article severe if a patient experiences two or more of the following: hemoglobin $<7 \mathrm{~g} / \mathrm{dl}$, ANC $<500$ cells $/ \mathrm{mm}^{3}$, and platelet count $<50 \times 10^{3}$ cells $/ \mathrm{mm}^{3}$. The mechanism underlying pancytopenia mainly involves bone marrow infiltration, bone marrow aplasia, and blood cell destruction that results in peripheral blood leakage [1]. Suppression of bone marrow varies widely in the pediatric population but may occur due to toxins, infection, or malignant cell infiltrates that can lead to hypocellular bone marrow function. Drug-induced pancytopenia is also a rare but secondary cause of bone marrow suppression due to direct bone marrow original author(s) and the source, provide a link to the Creative Commons licence, and indicate if changes were made. The images or other third party material in this article are included in the article's Creative Commons licence, unless indicated otherwise in a credit line to the material. If material is not included in the article's Creative Commons licence and your intended use is not permitted by statutory regulation or exceeds the permitted use, you will need to obtain permission directly from the copyright holder. To view a copy of this licence, visit http://creativecommons.org/licenses/by/4.0/. The Creative Commons Public Domain Dedication waiver (http://creativeco mmons.org/publicdomain/zero/1.0/) applies to the data made available in this article, unless otherwise stated in a credit line to the data. 
toxicity, immune-mediated (complement or antibodymediated) cell destruction, and hapten formation, and directly affects myeloid precursors [2, 3]. An in vitro study of several beta-lactam antibiotics established the presence of well-differentiated myeloid cells and copious granulocyte precursors along with dose-dependent suppression of granulopoiesis [4]. Antibody-mediated hemolytic anemia and thrombocytopenia have also been established in meropenem-treated patients $[5,6]$. Several medications can cause pancytopenia including chemotherapeutics, antiepileptics, antidepressants, and antibiotics $[3,5,7]$. A case-control epidemiological surveillance study was conducted over a follow-up period of 78.7 million person-years to assess the incidence of drug-induced agranulocytosis. Around 396 confirmed cases of acute neutropenia were observed, with an overall incidence of 3.5:1 million per year [8]. It was found that agranulocytosis clearly increased the risk of mortality, with a fatality rate of $9.1 \%$. The most common drugs causing agranulocytosis were dipyrone $(16 \%)$, beta-lactam antibiotics $(12.0 \%)$, ticlopidine (11.1\%), antithyroid drugs (7.2\%), and sulfonamide antibiotics (5.4\%) [8].

Meropenem is one of the beta-lactam antibiotics that can cause serious and life-threatening neutropenia. It is a bactericidal broad-spectrum antibiotic with grampositive, gram-negative, and anaerobic coverage, and is mainly used in the treatment of severe gram-negative infections in neonates including severe sepsis, meningitis, and complicated intra-abdominal infections such as necrotizing enterocolitis (NEC), one of the most common gastrointestinal emergencies and a major cause of morbidity and mortality in preterm neonates. For improved clinical outcomes, early recognition and aggressive management with broad-spectrum or combination antimicrobial agents is most often undertaken to treat NEC [9]. Because of its broad-spectrum activity, meropenem is an agent of great utility [10]. Based on the increasing trends of morbidity and mortality due to multidrug-resistant gram-negative bacterial infections in our neonatal intensive care unit (NICU), and following institutional guidelines, other antibiotics such as vancomycin and colistin are also used [11-13] after infectious disease (ID) consultation. The most common adverse effects of meropenem are constipation or diarrhea, nausea, vomiting, rashes, and diaperarea moniliasis in pediatric patients [14]. Some cases of meropenem-induced neutropenia have been reported [15]. However, no known case of meropenem-induced pancytopenia in neonates has yet been published. Here we report an event of meropenem-induced pancytopenia in a neonate admitted to the NICU of a tertiarycare hospital.

\section{Case presentation}

A newborn Pakistani baby was transferred to the intensive care unit due to prematurity, low birth weight, and intrauterine growth retardation. Her birth weight was $0.71 \mathrm{~kg}$ and APGAR scores were 3 at 1 minute and 4 at 5 minutes. Delivered by emergency C-section at 29 weeks due to raised blood pressure and fetal distress, she was initially kept on continuous positive airway pressure (CPAP) and given nothing through the mouth, and total parenteral nutrition (TPN) was started. Caffeine was loaded at $20 \mathrm{mg} / \mathrm{kg}$ and continued as the standard of care for apnea of prematurity. A prophylactic dose of $1 \mathrm{mg}$ of vitamin $\mathrm{K}$ was given. During the first 24 hours, complete blood count $(\mathrm{CBC})$ results were $\mathrm{WBC}$ of $18.3 \times 10^{3}$ cells/ $\mathrm{mm}^{3}$, ANC of 1244 cells $/ \mathrm{mm}^{3}$, platelet count of $166 \times 10^{3}$ cells $/ \mathrm{mm}^{3}$, and hemoglobin of $17.8 \mathrm{~g} / \mathrm{dl}$. On the second day of life (DOL), ampicillin and gentamicin were started as empirical therapy, and the $\mathrm{CBC}$ report showed WBC $4 \times 10^{3}$ cells $/ \mathrm{mm}^{3}$, ANC of 760 cells $/ \mathrm{mm}^{3}$, platelet count of $152 \times 10^{3}$ cells $/ \mathrm{mm}^{3}$, and hemoglobin of $15.9 \mathrm{~g} / \mathrm{dl}$. In addition, fluconazole was started as antifungal prophylaxis. The patient was given phototherapy. Chest X-ray and ultrasound of the head were performed, with normal findings. CPAP was tapered to high flow on merit, and blood culture was sent.

On the fourth DOL, the baby developed issues of severe respiratory distress and abdominal distension along with metabolic acidosis. She was intubated and kept on synchronized intermittent mandatory ventilation (SIMV) mode. The CBC results showed ANC of $912 \mathrm{cells} / \mathrm{mm}^{3}$, platelet count of $99 \times 10^{3}$ cells $/ \mathrm{mm}^{3}$, and hemoglobin of $12.7 \mathrm{~g} / \mathrm{dl}$. Inotropic support was started, and antibiotics were escalated to meropenem $20 \mathrm{mg} / \mathrm{kg}$ every 12 hours, vancomycin $10 \mathrm{mg} / \mathrm{kg}$ once daily, and colistin at a loading dose of $5 \mathrm{mg} / \mathrm{kg}$ with a maintenance dose of $1.5 \mathrm{mg} / \mathrm{kg}$ every 12 hours. Blood culture showed no growth. After ID consult, vancomycin was discontinued on the third day and a decision was made to continue meropenem and colistin [11-13] to manage NEC and sepsis.

On the fifth DOL, echocardiogram was performed and showed patent ductus arteriosus (PDA) of $3 \mathrm{~mm}$ with severe persistent pulmonary hypertension of the newborn (PPHN). Acetaminophen was started for the next 5 days. On the sixth day of meropenem therapy, the platelet count dropped to $42 \times 10^{3}$ cells $/ \mathrm{mm}^{3}$, treated in line with sepsis-associated thrombocytopenia [16], and managed by transfusion of $10 \mathrm{ml} / \mathrm{kg}$ platelet units [17]. Meropenem and colistin were discontinued on the eighth day of therapy, and trophic feeding was started. An echocardiogram was repeated on day 11 , which showed a closed PDA and moderate PPHN. On the 18th DOL, the child was successfully extubated and kept on high-flow oxygen. There was slow progress in feeding. 
On the 22nd DOL, the baby had tachycardia and an episode of $99.7^{\circ} \mathrm{F}$ fever. Thus, septic workup was done and showed WBC count of $17.4 \times 10^{3}$ cells $/ \mathrm{mm}^{3}$, ANC of $12,632.4 \mathrm{cells} / \mathrm{mm}^{3}$, and platelets of $203 \times 10^{3} \mathrm{cells} / \mathrm{mm}^{3}$. C-reactive protein (CRP) was $77 \mathrm{mg} / \mathrm{l}$ and renal function was normal (blood urea nitrogen [BUN] of $11 \mathrm{mg} / \mathrm{dl}$ and creatinine of $0.2 \mathrm{mg} / \mathrm{dl}$ ). Meropenem was started in meningitic doses of $40 \mathrm{mg} / \mathrm{kg}$ every 8 hours [10] along with vancomycin $15 \mathrm{mg} / \mathrm{kg}$ every 12 hours.

In the microbiological investigation, urine and cerebrospinal fluid (CSF) cultures were found to be negative, but the blood culture was positive for Staphylococcus species (not aureus). Blood culture repeated after 48 hours was positive for carbapenem-sensitive Klebsiella pneumoniae. The baby was moved to the isolation room. On the 24th DOL, the baby developed severe thrombocytopenia, with a platelet count of $22 \times 10^{3}$ cells $/ \mathrm{mm}^{3}$, managed with the transfusion of $10 \mathrm{ml} / \mathrm{kg}$ platelet units [17].

On the 25th DOL, an episode of generalized tonicclonic fit occurred for which single-dose diazepam and a loading dose of phenobarbitone were given initially and then continued with maintenance doses of phenobarbitone. Due to significant metabolic acidosis and desaturation, the baby was re-intubated. After ID consult, meropenem was continued in meningitic doses and vancomycin was discontinued. SIMV and a central line were placed. TPN was started with nothing per oral status.

Blood gases were monitored, and the baby was extubated after 4 days and switched to CPAP. Phenobarbitone was discontinued after 6 days of therapy, and the baby was seizure-free through the remainder of the hospital stay. All repeat blood cultures were negative for any growth including CSF culture. The ID team was on board and decided to continue meropenem for a total of 14 days post-negative culture in septic doses of $20 \mathrm{mg} / \mathrm{kg}$, and vancomycin was discontinued after 6 days. All repeated blood cultures obtained on the 27th and 30th DOL confirmed no pathogenic growth.

On the 33rd DOL, the $\mathrm{CBC}$ report showed $\mathrm{WBC}$ of $8.7 \times 10^{3}$ cells $/ \mathrm{mm}^{3}$, ANC of 4576 cells $/ \mathrm{mm}^{3}$, platelets of $78 \times 10^{3}$ cells $/ \mathrm{mm}^{3}$, and hemoglobin of $10.8 \mathrm{~g} /$ dl. On the 36th DOL, the CBC report showed WBC of $5.1 \times 10^{3}$ cells $/ \mathrm{mm}^{3}$, ANC of 2917 cells $/ \mathrm{mm}^{3}$, platelets of $29 \times 10^{3}$ cells $/ \mathrm{mm}^{3}$, and hemoglobin of $9.2 \mathrm{~g} / \mathrm{dl}$. The baby was managed for thrombocytopenia with platelet transfusion.

On the 37th DOL, hemoglobin dropped to $8.3 \mathrm{~g} /$ $\mathrm{dl}$ in the evening, and platelet count improved to $63 \times 10^{3}$ cells $/ \mathrm{mm}^{3}$, WBC was $4.8 \times 10^{3}$ cells $/ \mathrm{mm}^{3}$, and ANC was 1285 cells $/ \mathrm{mm}^{3}$. On the 39th DOL, a marked reduction was observed in ANC to 816 cells $/ \mathrm{mm}^{3}$, platelets of $38 \times 10^{3}$ cells $/ \mathrm{mm}^{3}$, and hemoglobin of $8.3 \mathrm{~g} / \mathrm{dl}$, and the baby received blood transfusion to manage it. For constant issues, a hematological consult was taken and a decision was made to manage the baby symptomatically with $10 \mathrm{ml} / \mathrm{kg}$ platelet units at a platelet count $<50$ [17] and $15 \mathrm{ml} / \mathrm{kg}$ packed cell transfusion at hemoglobin $<10$ $\mathrm{g} / \mathrm{dl}[18]$.

On the 40th DOL, meropenem was discontinued 14 days after negative culture (total of 19 days of meropenem therapy). On the same day the platelet count was $34 \times 10^{3}$ cells $/ \mathrm{mm}^{3}$, ANC was 818 cells $/ \mathrm{mm}^{3}$, and hemoglobin was $10.2 \mathrm{~g} / \mathrm{dl}$, and the baby was transfused to manage these issues. After discontinuation of meropenem, the baby was continuously monitored for hematological changes, and low counts persisted for 3 days. Improved ANC of $>1500$ cells $/ \mathrm{mm}^{3}$ was reported on the fourth day, and platelet count of $>150 \times 10^{3}$ cells $/ \mathrm{mm}^{3}$ was reported for the first time on the sixth day of meropenem discontinuation, but hemoglobin was still low (Fig 1). CPAP was tapered gradually to nasal prongs. The peripherally inserted central catheter was removed, and orogastric (OG) tube feeding was commenced. The baby was discharged on the 48th DOL on iron supplements with follow-up monitoring of CBC. Hemoglobin level of $11.2 \mathrm{~g} / \mathrm{dl}$ was found on the 59th DOL.

\section{Discussion}

Drug-induced pancytopenia is a rare hematological problem in neonatal clinical practices, evaluated based on a complete underlying pathological history, physical examination, and vigilant interpretation of biochemical, radiological, histopathological, and hematological findings [19]. Concerns have been raised about hematological adverse effects of several beta-lactamase inhibitors [8]. This neonatal case documents meropenem-induced pancytopenia and emphasizes cautious laboratory monitoring for patients receiving meropenem therapy.

Sepsis is another known etiology of pancytopenia. Although the neonate in the present case had a blood culture positive for $K$. pneumoniae, the results of all repeated blood cultures were negative, showing the resolution of sepsis. Van Tuyl et al. [20] also reported a case of a neonate receiving meropenem in meningitic doses of $40 \mathrm{mg} / \mathrm{kg} /$ day to treat meropenem-susceptible Enterobacter cloacae in blood culture. The baby developed meropenem-induced neutropenia on the 13th day of therapy, with ANC of 288 cells $/ \mathrm{mm}^{3}$. The decision was made to discontinue meropenem on the 19th day of therapy instead of the initially planned 21 days. In the present case, the baby continued to receive meropenem treatment and was managed for hematological problems based on institutional guidelines and culture sensitivity. Initially, hematological changes were not considered as directly meropenem-induced. 


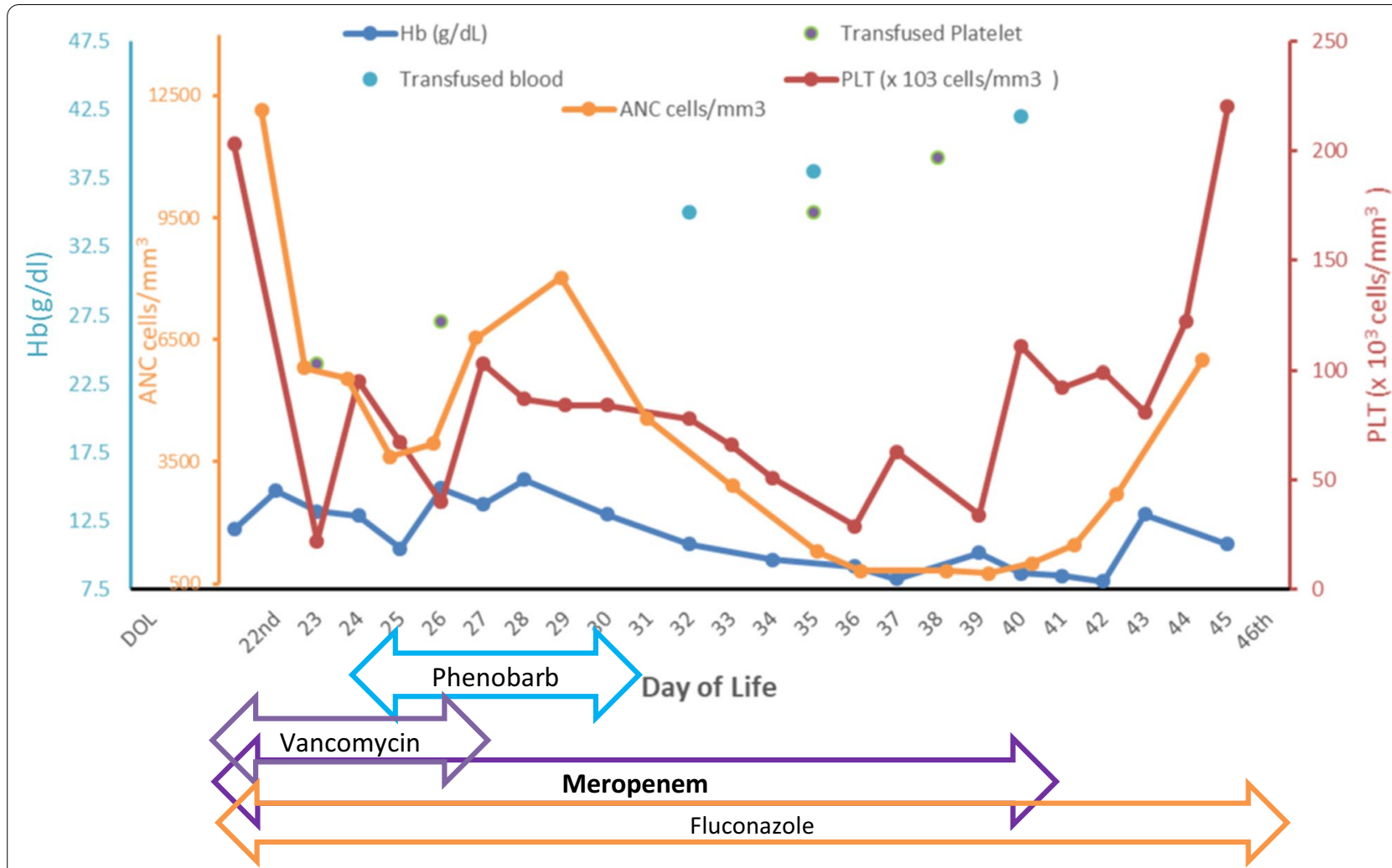

Fig. 1. Hematological changes and timing of medication during hospitalization

Recently published reports also support the notion of carbapenem-induced hematological disorders. A case report by Estella and colleagues [21] described meropenem-induced pancytopenia in a 3-year-old patient at $100 \mathrm{mg} / \mathrm{kg}$ given every 8 hours to manage the regrowth of meropenem-sensitive Morganella morganii in CSF cultures. Huang et al. [6] reported a case of meropenem-induced immune thrombocytopenia in a 59-year-old patient, by detecting meropenem-dependent platelet antibodies and platelet count recovery after discontinuation of meropenem. Oka et al. [5] reported the development of severe anemia with clinical signs in a 76-year-old female patient, who received $2 \mathrm{~g}$ meropenem per day. On further investigation, they found that a direct antiglobulin test (DAT) was positive for immunoglobulin G (IgG) and C3d, and reported the presence of meropenem-dependent antibodies in the patient's serum [5].

The absence of drug-dependent antibody testing and bone marrow aspiration prevent us from drawing a firm conclusion regarding the mechanism of meropeneminduced pancytopenia in the present case. However, the hematological findings with the progressive development of thrombocytopenia, anemia, and then neutropenia suggest a possible mechanism of suppression of granulopoiesis or antibody-mediated destruction, as reported in recent studies [5, 6].

During hospitalization, the neonate received other medications, which have been reported to exert hematological effects. The baby initially received ampicillin, gentamicin, and fluconazole, and then received meropenem, colistin, vancomycin, and phenobarbital. However, severe thrombocytopenia developed on the sixth day of the first course of meropenem therapy, when the baby was also on colistin and fluconazole. This issue was resolved when meropenem was discontinued. During the second course of meropenem therapy, the baby again developed severe thrombocytopenia on the third day, while also receiving vancomycin, fluconazole, and phenobarbital. Phenobarbital-induced hematological abnormalities are reported in animal and adult studies [22, 23], and therefore it was discontinued on the sixth day. No seizures were observed but counts did not improve. However, the baby developed severe anemia and neutropenia while receiving fluconazole and meropenem only. After meropenem discontinuation, severe anemia and neutropenia showed a resolving trend for 3 days. Severe neutropenia resolved on the fourth day, and hemoglobin was reported at $>10$ $\mathrm{g} / \mathrm{dl}$ without transfusion on the seventh day of meropenem discontinuation, while fluconazole therapy was 
continued from the beginning until the 56th DOL, which further confirms the association of meropenem-induced hematological changes in this baby. It was also confirmed that the baby did not experience any additional infection even though she was not discharged on any antibiotic, which correlates with the fast recovery of blood counts after meropenem discontinuation.

\section{Conclusions}

In the present neonatal case, the gradual onset of hematological irregularities correlates with the commencement of meropenem therapy, and our observations are also verified by previously published evidence. The follow-up $\mathrm{CBC}$ count further established the resolution of pancytopenia after discontinuation of meropenem. Neonatal pancytopenia may lead to serious health complications; therefore, clinicians and pharmacists need to vigilantly monitor $\mathrm{CBC}$ counts in this vulnerable population, even when administering meropenem in septic doses for the recommended duration.

\section{Patient perspective}

From the perspective of the patient's father, it was a rare case to have such kind of adverse events in a neonate with the normal treatment regimen. He was shared about all the events and he admired the team for the timely and effectively managing the issues and finally $100 \%$ recovery on the follow-ups.

\section{Abbreviations}

ANC: Absolute neutrophil count; CBC: Complete blood count; DOL: Day of life; CPAP: Continuous positive airway pressure; TPN: Total parenteral nutrition; SIMV: Synchronized intermittent mandatory ventilation; NEC: Necrotizing enterocolitis; PDA: Patent ductus arteriosus; PPHN: Persistent pulmonary hypertension of the newborn; CRP: C-reactive protein; ID: Infectious disease.

\section{Acknowledgements}

We acknowledge the kind support of Abdul Moiz Hussain for providing technical support in the process of final submission and language review. This study was conducted in the neonatal intensive care unit of Aga Khan University Hospital, Karachi, Pakistan.

\begin{abstract}
Authors' contributions
GA: Substantial contributions to the conception or design of the work. Performed the study, analysis, or interpretation of patient information. Major contributor in writing the manuscript. KH: Supervised the study and analyzed and interpreted the patient data regarding the hematological changes with therapy. Revised the work critically for important intellectual content. SS: Supervised the study and analyzed and interpreted the patient data regarding the hematological changes with therapy. Final approval of the version published. NM: Wrote the initial draft of the case report. AM: Co-wrote the initial draft. SI: data collection and interpretation. Jl: data collection and interpretation. All authors read and approved the final manuscript.
\end{abstract}

\section{Funding}

No source of funding in the research.

\section{Availability of data and materials}

All data generated or analyzed during this study are included in the published article. The data sets used and/or analyzed during the current study are available from the corresponding author on reasonable request. Please contact the author for data requests.

\section{Ethics approval and consent to participate}

This case report was exempted from formal approval by the Ethical Review Committee, Aga Khan University Karachi, Pakistan.

\section{Consent for publication}

Written informed consent was obtained from the patient's legal guardian(s) for publication of this case report and any accompanying images. A copy of the written consent is available for review by the Editor-in-Chief of this journal.

\section{Competing interests}

The authors declare that they have no competing interests.

\section{Author details}

${ }^{1}$ Department of Pharmacy, Main Pharmacy Aga Khan University Hospital, Stadium Road, P.O Box 3500, Karachi 74800, Pakistan. ${ }^{2}$ Department of Paediatrics \& Child Health, Aga Khan University, Karachi, Pakistan.

Received: 8 September 2020 Accepted: 14 December 2020

Published online: 29 January 2021

\section{References:}

1. Khunger JM, Arulselvi S, Sharma U, Ranga S, Talib V. Pancytopenia-a clinico haematological study of 200 cases. Indian J Pathol Microbiol. 2002:45(3):375

2. Andrès $E$, Maloisel F. Idiosyncratic drug-induced agranulocytosis or acute neutropenia. Curr Opin Hematol. 2008;15(1):15-21.

3. Bhatt V, Saleem A. Drug-induced neutropenia-pathophysiology, clinical features, and management. Ann Clin Lab Sci. 2004;34(2):131-7.

4. Neftel KA, Hauser SP, Müller MR. Inhibition of granulopoiesis in vivo and in vitro by $\beta$-lactam antibiotics. J Infect Dis. 1985;152(1):90-8.

5. Oka S, Shiragami H, Nohgawa M. Intravascular hemolytic anemia in a patient with antibodies related to meropenem. Intern Med. 2015;54(10):1291-5.

6. Huang R, Cai GQ, Zhang JH, Liu FX, Ma JQ, Liu H, et al. Meropeneminduced immune thrombocytopenia and the diagnostic process of laboratory testing. Transfusion. 2017;57(11):2715-9.

7. Ouwehand W, Smith G, Ranasinghe E. Management of severe alloimmune thrombocytopenia in the newborn. Arch Dis Child-Fetal Neonatal Ed. 2000;82(3):F173-5.

8. Ibáñez L, Vidal X, Ballarín E, Laporte J-R. Population-based drug-induced agranulocytosis. Arch Intern Med. 2005;165(8):869-74.

9. Neu J, Walker WA. Necrotizing enterocolitis. N Engl J Med. 2011;364(3):255-64.

10. van den Anker JN, Pokorna P, Kinzig-Schippers M, Martinkova J, de Groot R, Drusano G, et al. Meropenem pharmacokinetics in the newborn. Antimicrob Agents Chemother. 2009;53(9):3871-9.

11. Saleem AF, Ahmed I, Mir F, Ali SR, Zaidi AK. Pan-resistant Acinetobacter infection in neonates in Karachi, Pakistan. J Infect Dev Ctries. 2010;4(01):030-7.

12. Saleem AF, Qamar FN, Shahzad H, Qadir M, Zaidi AK. Trends in antibiotic susceptibility and incidence of late-onset Klebsiella pneumoniae neonatal sepsis over a six-year period in a neonatal intensive care unit in Karachi, Pakistan. Int J Infect Dis. 2013;17(11):e961-5.

13. Ambreen G, Salat MS, Hussain K, Raza SS, Ali U, Azam I, et al. Efficacy of colistin in multidrug-resistant neonatal sepsis: experience from a tertiary care center in Karachi, Pakistan. Arch Dis Child. 2020.

14. Bielicki JA, Sharland M, Heath PT, Walker AS, Agarwal R, Turner P, et al. Evaluation of the coverage of 3 antibiotic regimens for neonatal sepsis in the hospital setting across Asian countries. JAMA Netw Open. 2020;3(2):e1921124-e.

15. Burckhardt M. Neutropenia in an infant: case report. Reactions. 2013;1465:26-7.

16. Ree IM, Fustolo-Gunnink SF, Bekker V, Fijnvandraat KJ, Steggerda SJ, Lopriore E. Thrombocytopenia in neonatal sepsis: incidence, severity and risk factors. PLoS ONE. 2017;12(10):e0185581. 
17. Strauss RG. Platelet transfusions in neonates: questions and answers. Expert Rev Hematol. 2010;3(1):7-9.

18. Aher S, Malwatkar K, Kadam S, editors. Neonatal anemia. Seminars in fetal and neonatal medicine. Amsterdam: Elsevier; 2008.

19. Makheja KD, Maheshwari BK, Arain S, Kumar S, Kumari S. The common causes leading to pancytopenia in patients presenting to tertiary care hospital. Pak J Med Sci. 2013;29(5):1108.

20. Van Tuyl JS, Jones AN, Johnson PN. Meropenem-induced neutropenia in a neonate. J Pediatr Pharmacol Therap. 2016;21(4):353-7.

21. Estella J, Villanueva J, Calvo M, Toll MT, Alcorta I, Roca J, et al. Bone marrow aplasia and meropenem in a paediatric patient. Br J Haematol. 2000;111(3):984-5.
22. Haböck G, Pakozdy A. Haematological abnormalities in dogs during phenobarbital treatment. Wiener Tierärztliche Monatsschrift. 2012;99(9/10):242-9.

23. Focosi D, Kast RE, Benedetti E, Papineschi F, Galimberti S, Petrini M. Phenobarbital-associated bone marrow aplasia: a case report and review of the literature. Acta Haematol. 2008;119(1):18-21.

\section{Publisher's Note}

Springer Nature remains neutral with regard to jurisdictional claims in published maps and institutional affiliations.
Ready to submit your research? Choose BMC and benefit from:

- fast, convenient online submission

- thorough peer review by experienced researchers in your field

- rapid publication on acceptance

- support for research data, including large and complex data types

- gold Open Access which fosters wider collaboration and increased citations

- maximum visibility for your research: over 100M website views per year

At BMC, research is always in progress.

Learn more biomedcentral.com/submissions 